\title{
THE INFLUENCE OF LEARNING METHODS AND NATURALIST INTELLIGENCE ON CRITICAL THINKING SKILLS IN SCIENCE LEARNING
}

\author{
Suhirman \\ Universitas Islam Negeri Mataram, NTB, Indonesia \\ suhirman@uinmataram.ac.id
}

\begin{abstract}
The purpose of this research is to find out the influence of different learning methods and nauralist intelligence on critical thinking skills on science learning. This research method uses an experimental approach. The data in this resarch was collected with observation techniques for the implementation of learning and tests to measure naturalist intelligence and critical thinking skills. To determine the influence of different learning methods and nauralist intelligence on critical thinking skills on science learning, analysis was conducted with t-Test Two-Sample Assuming Equal Variances. There is an influence on students' nauralist intelligence level on critical thinking skills taught by problem-based learning methods as evidenced by the results of the analysis where tcount $=6.89>$ ttable $=2.03$, thus positively correlated with a determination coefficient of 0.58 . On the other hand, there is no influence on students' level of nauralist intelligence on critical thinking skills taught by regular learning methods, which is evidenced by the results of the analysis where tcount $=0.06=$ ttable $=2.03$, so it does not correlate positively with the coefficient of determination of 0.0001 . From various literature stipulated that problem based learning is a teaching approach that uses real-world problems as a context for students to learn about critical thinking and problem solving skills, as well as to obtain essential knowledge and concepts from the subject matter.
\end{abstract}

Keywords: Learning methods; problem-based learning; regular learning; naturalist intelligence; critical thinking skills.

\section{INTRODUCTION}

Science education has a very important and useful role in supporting life and contributing to the development of science in general. The quick advancement of science and innovation requires an individual to have certain aptitudes important to endure. Science Education adds to the improvement of understanding abilities on the best approaches to utilize science in day by day life and social obligation (Drago and Mih, 2015). 
Competitive generation is required in natural sciences and technologies that refer to critical thinking abilities (Setiawan et al., 2017). One of the most significant targets of Science Education is the improvement of basic reasoning and science proficiency (Drago and Mih, 2015).

Indonesian students are as yet feeble in the dominance of science. One of the shortcomings of optional science educators today is the frail capacity to create coordinated science learning (Rubini, Pusitasari, Ardianto, and Hidayat, 2018). Therefore, in science learning, an instructor needs to create basic deduction to make progress both in learning and, all things considered (Asrizal, Amran, Ananda, Festiyed, and Sumarmin, 2018).

Science educators and students in Indonesia should be furnished with basic deduction abilities to train science and science subjects (Suwono, Pratiwi, Susanto, and Susilo, 2017). Basic reasoning is significant for students to know, comprehend, and apply science and technology. Critical thinking depicts an individual's capacity to comprehend about laws, speculations, ideas, standards, confirmations and different other logical marvels.

Pointers of the bad quality of instruction can be resolved from systems, techniques, models and how to educate teachers. In general, the learning cycle at the center and secondary school level will in general utilize regular learning, for example, addresses, tasks, utilizing course readings that are more overwhelmed by instructors and detached understudies in learning. Learning isn't coordinated to discovering issues and getting arrangements, nor is it coordinated with genuine students. The 2013 educational program gives an option in contrast to a few learning methodologies for educators and students.

The ability to think students can also be developed by applying problembased learning (PBL) models (Nuswowati, Susilaningsih, Ramlawati, \& Kadarwati, 2017). PBL is a model that prioritizes the suitability of learning with things found in the daily lives of students (Nuswowati et al., 2017).

Problem based learning is an encouraging planned dependent on the genuine issues of life that is badly organized. An indefined issue is an 
ambiguous, dark, or vague issue (Fogarty, 1997; Jones, 1996) in Amyana, 2004. Learning dependent on issues can arouse understudies' curiosity, genuine, and fitting for scholarly turn of events and give chances to understudies to learn, in actuality, circumstances.

From the above description it can be concluded that problem-based learning is an effective approach in developing critical thinking skills and problem solving skills as well as to acquire essential knowledge and concepts from subject matter. Thus, the essence of problem-based learning is to use real-world problems as context for students to think critically and problemsolving.

Naturalist intelligence is the ability to recognize and classify various types of flora (plants) and fauna (animals) and other natural phenomena, such as animal origin, plant growth as well as sensitivity to morphology and physiology that exist in nature such as the formation of mountains, the formation of clouds, climate and weather, the onslance of rain, the formation of rivers, seas, lakes, forests, coastal forms and the formation of mangrove forests. So that this intelligence can be developed through activities related to natural phenomena. Similarly, it can be concluded that naturalist intelligence emphasizes the ability to recognize, distinguish, disclose and categorize what is found in nature and the environment. The point is the ability of students (humans) to recognize plants, animals and other parts of nature and the environment.

Learning strategies are one of the external factors that influence problem solving skills, student character and critical thinking skills. In addition to external factors, there are also internal factors, one of which is naturalist intelligence. Naturalist intelligence is part of the compound intelligence possessed by humans. This intelligence includes sensitivity to natural problems or phenomena and the ability to distinguish living and unserable beings. 


\section{THEORETICAL FRAMEWORK}

The abilities expected to confront the difficulties of the 21st century are instructing, perusing, composing, and checking exercises yet in addition about forming thinking aptitudes into basic reasoning skills. Critical thinking aptitudes are fundamental aptitudes that understudies need to adjust to the outside difficulties of the 21st century (Putra et al., 2018). Critical deduction, as one of the primary reasoning abilities, is viewed as one of the aptitudes of the 21st century that ought to be shrouded in training (Aljaafil and Şahin, 2019). One of the fundamental abilities that is frantically required in the time of globalization is basic reasoning aptitudes (Bustami, Syafruddin, and Afriani, 2018; Anazifa and Djukri, 2017; Khasanah, Sajidan, and Widoretno, 2017). Critical reasoning abilities are one of the significant abilities in entering the universe of work and in carrying on with life, so the nature of human life can be better.

Thinking skills are the main competency to solve problems, especially high-level thinking skills (Puspitawati et al., 2018). Critical thinking becomes very important because the real problems in today's life are increasingly complex (Mutakinati, Anwari, \& Yoshisuke, 2018). High-level thinking skills are needed to overcome the problems of daily life (Son, Prayitno, \& Mariadi, 2018). The ability to think scientifically can be considered as part of critical thinking (Suciati, Ali, Imaningtyas, Anggraini, \& Philanthropy, 2018). There are 4 skills needed for the 21 st century generation known as 4C, namely creativity and innovation, critical thinking and problem solving, communication, and collaboration (creativity and innovation, critical thinking and problem solving, communication, and collaboration) (Astuti et al., 2019; Bedir, 2019).

In science learning activities, students' critical thinking skills have not received serious attention from teachers. Teachers should be more creative, to foster student activity (Sada, 2019). Therefore, every level of education has an important role to play in improving the critical thinking skills of students, especially biology students. The short-term goal of critical thinking skills is to 
strengthen students' conceptual understanding especially in Natural Science subjects (Khasanah et al., 2017).

Critical thinking cannot be transferred through the text of a book, but it is needed through thought and the ability to evaluate or assess the credibility, validity and value of something (Aljaafil \& Şahin, 2019). critical thinking is not only about teaching students how to think but also training elastic and active to think about, investigate and examine new and old information or facts learned (Suciati et al., 2018).

Critical thinking aptitudes accomplished by students in Indonesia through both execution of pjpbl model and problem posing learning to have no noteworthy contrast (Rochmawati, Wiyanto, and Ridlo, 2019). Designing and mediating methodically to make a learning situation should be done and explored adequately in creating thinking abilities (Tiruneh, De Cock, and Elen, 2018; Delaney, Pattinson, Mccarthy, and Beecham, 2017).

Learning activities in schools have not been able to improve students' critical thinking optimally (Anazifa \& Djukri, 2017). The use of learning models such as problem based-learning (Kurniawan et al., 2019). Students' thinking skills can also be developed by applying problem-based learning models (Nuswowati et al., 2017). Teachers should be more creative, to foster student activity (Sada, 2019). PBL is a student-centered approach and requires prior general knowledge. Students are more active in obtaining information from a variety of sources. Since it was first implemented until now, problem-based learning has become one of the methods that received considerable attention in Indonesia, especially in the world of secondary and upper education.

According to Levin, says problem-based learning is an approach that encourages students to apply critical thinking skills, problem-solving skills and knowledge related to real-world problems and issues. So that learning is more student-centered, teachers act more as facilitators and motivators (Robert B.Levin, 2001). Whereas according to Arends problem-based learning is a learning approach in which students work on authentic problems with a 
view to compiling their own knowledge, developing high levels of inquisic and thinking skills, developing self-reliance and confidence (Richard I.Arends, 1997).

In line with the opinion above Santrock suggests problem-based learning is learning that emphasizes more on authentic problem solving like problems that occur in lifestyle (John W. Santrock, 2004). Affirmed by Ramsay \& Sorrel problem-based learning may be a student-centered learning method, which may improve students' ability to research, synthesize, and evaluate problems.Problem-based learning also can be used as a teaching strategy designed supported real unstructured problems and seeks to seek out meaningful solutions (James Ramsay and Elbert Sorrel, 2006).

In PBL, students work together in groups to seek out and solve problems and make decisions (Haji A.G, Safriana, \& Safitri R., 2015). PBL may be a model that prioritizes the suitability of learning with things found within the daily lives of scholars (Nuswowati et al., 2017). This is in line with the implementation of the 2013 Curriculum which recommends learning be through with a scientific approach through the PBL method. Problem-based learning (PBL), ready to improve and develop knowledge, competency, problem solving and communication skills (Delaney, Pattinson, Mccarthy, \& Beecham, 2017).

Problem-based learning may be a learning model designed during a learning procedure that begins with a selected problem (Witte \& Rogge, 2016; Sadia, 2014). Arends identifies 5 (five) phases in problem-based learning and behavior required of teachers for every phase (Richard I. Arends, 1997). the method begins with the student's orientation on the difficulty, a introduce which the teacher sets the direction of learning and motivates the scholar. The next phase organizes students to find out . Next, the teacher guides to direct students to customize important tasks to unravel problems. Guide the investigation in groups, humidize and present the work, and eventually conclude the method with evaluation activities. 
PBL requires students to develop knowledge independently or cooperation in groups to find a real solution to a problem. Complex, contextual and illstructure problems will give students the opportunity to develop analytical, evaluative, and reflective thinking skills and develop their creativity in digging up information, developing possible solutions, and creating a variety of resources to solve problems to solve (Tsai \& Chiang, 2013). PBL enhances student confidence, provides a supportive environment that encourages teamwork, improves interpersonal communication and problem-solving skills, and encourages self-awareness (Moody, Mchugh, Baker, Santizo, \& Schechter, 2018; Aldarmahi, 2016). According to Aldarmahi (2016), PBL is beneficial for students in compiling their knowledge, developing reasoning processes, improving their self-learning skills, and improving their intrinsic motivation to learn.

The concept of multiple Intellegence originated with Howard Gardner's 1983 book Frames of Mind supported several years of research on human cognitive capacity, Gardner rejects the idea that human cognition is one unit which individuals have only one intelligence.Although most people show different mastery. Individuals have some intelligence and merge into one unit forming quite high personal abilities. Howard Garnerd introduces and promotes project zero research in America associated with dual intelligence. His theory dispels the all-time assumptions about human intelligence. The results showed that no unit of act uses just one quite intelligence, but rather all intelligence.

\section{RESEARCH METHODOLOGY}

This research method uses an experimental approach. The data in this study was collected with observation techniques, naturalist intelligence tests and critical thinking skills tests. This hypothesis test can be carried out first done hypothesis requirements test, namely normality and homogeneity test. The normality test of the data was conducted with lilifort test with criteria if 
the data distribution is normal and vice versa. While the data homogeneity test uses the Barlett test. The homogeneity test criteria if F statistics (calculate) > F Critical, then the data is said to be homogeneous and vice versa.

To determine the effect of different learning methods and nauralist intelligence on critical thinking skills in science learning, an analysis was carried out using the two-sample assuming equal variances t-test. The analysis stages are: First, test the differences in naturalist intelligence between students who are taught by problem-based learning methods and regular learning methods. Second, test the differences in critical thinking skills for students who are taught by problem-based learning methods and regular learning methods. The test criterion is if $\mathrm{t}$ stat $\geq \mathrm{t}$ critical two-tail, then statistically there is a difference, and vice versa. Meanwhile, to determine the effect of students' naturalist intelligence on students' thinking skills in science learning was done by using correlation analysis test.

\section{FINDINGS AND DISCUSSION}

The data from this research is in the form of naturalist intelligence data and critical thinking skills of students. This data was obtained from MTsN 1 Mataram grade VII students in the 2019 school year collected with test techniques. This research sample is a class of VII A and VII C taught by different methods. VII A classes are taught by problem-based methods, while VIIC classes are taught with regular learning methods. After the study was done with both methods in both sample classes, data collection was done with tests.

Variance similarity tests and average difference tests of critical thinking skills data that follow problem-based learning methods and regular learning methods are:

Table 1. Variance similarity test

\begin{tabular}{lccc}
\hline Parameters & PBL & PR \\
\hline Var & 13.1 & & 13.3 \\
Dk & 34 & & 34 \\
F $_{\text {count }}$ & & 1.02 & \\
dk1 & \multicolumn{2}{c}{34} & \\
\hline
\end{tabular}




\begin{tabular}{lcc}
\hline Parameters & PBL & PR \\
\hline dk2 & 34 & \\
F $_{\text {critical }}$ & 1.77 & \\
Criteria & Homogen & \\
\hline
\end{tabular}

Based on the table above, further homogeneity testing was conducted using the Barlett test, through a variance similarity test of critical thinking skills data taught with problem-based learning methods and regular learning methods showing the population is homogeneous, this is evidenced by Fcount $=1.02<$ Fcritical $=1.77$.

Table 2. Average difference test

\begin{tabular}{lcc}
\hline Category & PBL & PR \\
\hline Average & 82.31 & 80.29 \\
Variance & 13.10 & 13.33 \\
$\mathbf{N}$ & 35 & 35 \\
$\mathbf{D k}$ & \multicolumn{2}{c}{68} \\
$\mathbf{t}_{\text {count }}$ & \multicolumn{2}{c}{2.33} \\
$\mathbf{t}_{\text {critical }}$ & \multicolumn{2}{c}{2.00} \\
Criteria & There's a difference \\
\hline
\end{tabular}

The average score of a student's naturalist intelligence and critical thinking skills gained by students with problem-based methods was higher (82.31) compared to the mean gain of students studying with regular learning methods (80.29). The average test results of data on critical thinking skills that follow problem-based learning methods and regular learning methods are different, this can be seen from the data analysis results where tcount $=2.33>$ tcritical $=2.00$.

The following are the results of correlation analysis between students' naturalist intelligence levels and students' critical thinking skills taught with problem-based learning methods.

Table 2. Correlation test

\begin{tabular}{lcc}
\hline Category & PBL & PR \\
\hline R & 0.7635 & 0.010848 \\
KD & $58.29 \%$ & 0.01 \\
$\mathbf{N}$ & 35 & 35 \\
\hline
\end{tabular}




\begin{tabular}{lcc}
\hline Tobs & 6.89359 & 0.062245 \\
Dk & 34 & 34 \\
Tstat & 2.032245 & 2.032245 \\
Criteria & There is an influence & No influence \\
\hline
\end{tabular}

Based on the results of the analysis using correlation tests shows that the level of naturalist intelligence of students taught by problem-based learning methods has a significant influence on the critical thinking skills of students, where the results Fcount $=6.89>$ Fstat $=2.03$. It can also be seen from the following diagram, that the naturalist intelligence of students taught by problem-based learning methods is positively correlated with students' critical thinking skills.

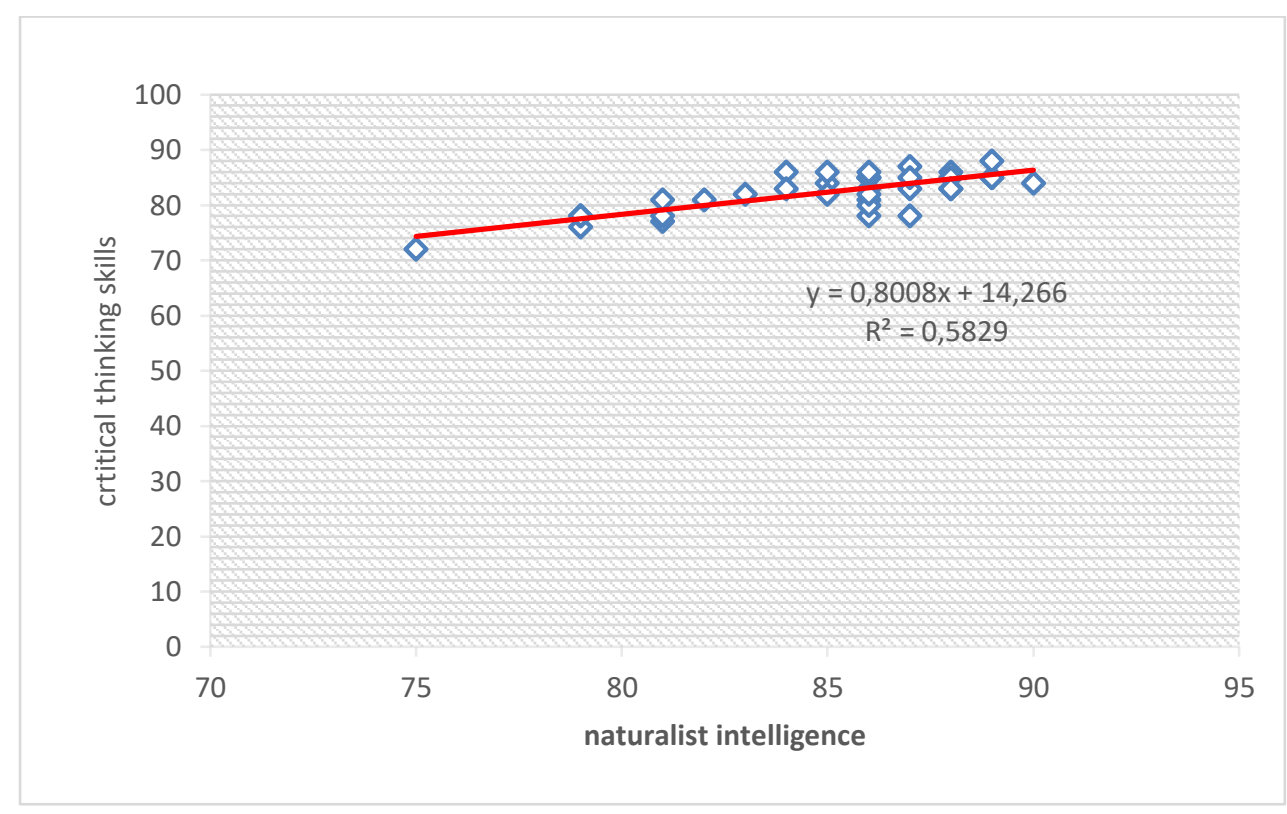

Figure 1. Correlation of naturalist intelligence with students' critical thinking skills with problem-based learning methods

Testing using this correlation test analysis showed a positive relationship of $\mathrm{r}=0.7635$ which means the correlation is very strong with the equation $\mathrm{Y}=$ $0.800 \mathrm{x} 14,266$ with a determination coefficient price of $\mathrm{R} 2=0.5829$, this indicates that the contribution of students' naturalist intelligence level to critical thinking skills is $58 \%$.

In problem-based learning methods teachers can innovate learning, such as tracking or tracing students' early or basic scientific abilities, especially in 
relation to natural sciences; in the application of problem based learning methods students are more active and more independent in studying materials, especially materials that have intergration with other cross-science materials as well as students can develop analytical thinking skills.

This is in accordance with the opinions of David Bound and Grahame I. Feletti (1997) that in problem-based learning teachers can perform new breakthroughs, such as multiplying students' basic knowledge, especially basic science, problem-based learning methods are student oriented; students are able to think critically and are able to develop initiatives.So students can easily gain an understanding of the materials related to the experience.

According to (Roos, 2017), students with high naturalist intelligence have a strong affinity for nature. A strong affinity is demonstrated by his love of learning topics related to nature and its phenomena.

In problem based learning students are motivated to compile assumptions and hypotheses while reviewing various possible answers in the disolving of the problem at hand. Likewise, students have the opportunity to find important sources of information to solve problems.

Problem based learning is one of learning with an approach to authentic problems so that students can compose their own knowledge, develop higher skills, incuction, establish students, and increase self-confidence (Asikin, 2006). Ibrahim further said that problem based learning is a learning centered on students and encourages open inkuiri and free thinking. The whole problem-oriented learning process is to help students become independent (Ibrahim Muslim, 2003).

The positive influence above is important information for teachers to pay attention to the naturalistic intelligence aspects of students. By paying attention to the naturalist intelligence of the learner has indirectly noticed his motivation, mental, skill, achievement, and no less important is critical thinking skills. Environmental issues today are one of the important issues that are being discussed in various forums of international institutions. 
Problem based learning was developed to help students develop thinking skills, problem solving skills, moving and engaging various activities such as induction, deduction, classification and reasoning while also developing the ability to analyse, criticise and draw conclusions.

Naturalist intelligence is one of a variety of intelligence (multiple intellegences), problem solving skills are part of high-level thinking.Both are learning outcomes that need to be developed and improved in each student because the competencies are considered weak in Indonesia (Adisendjaja, Abdi, \& Fardhani, 2019). The achievement of learning outcomes is expected to improve students' intelligence.

Based on the results of the analysis shows that F count $=0.06>$ Fstat $=2.03$, means that the level of naturalist intelligence of students taught by regular learning methods has no real influence on students' critical thinking skills. The following diagram also shows that a student's naturalist intelligence does not correlate with a student's critical thinking skills.Here are the results of correlation analysis between students' naturalist intelligence levels and critical thinking skills taught with regular learning methods.

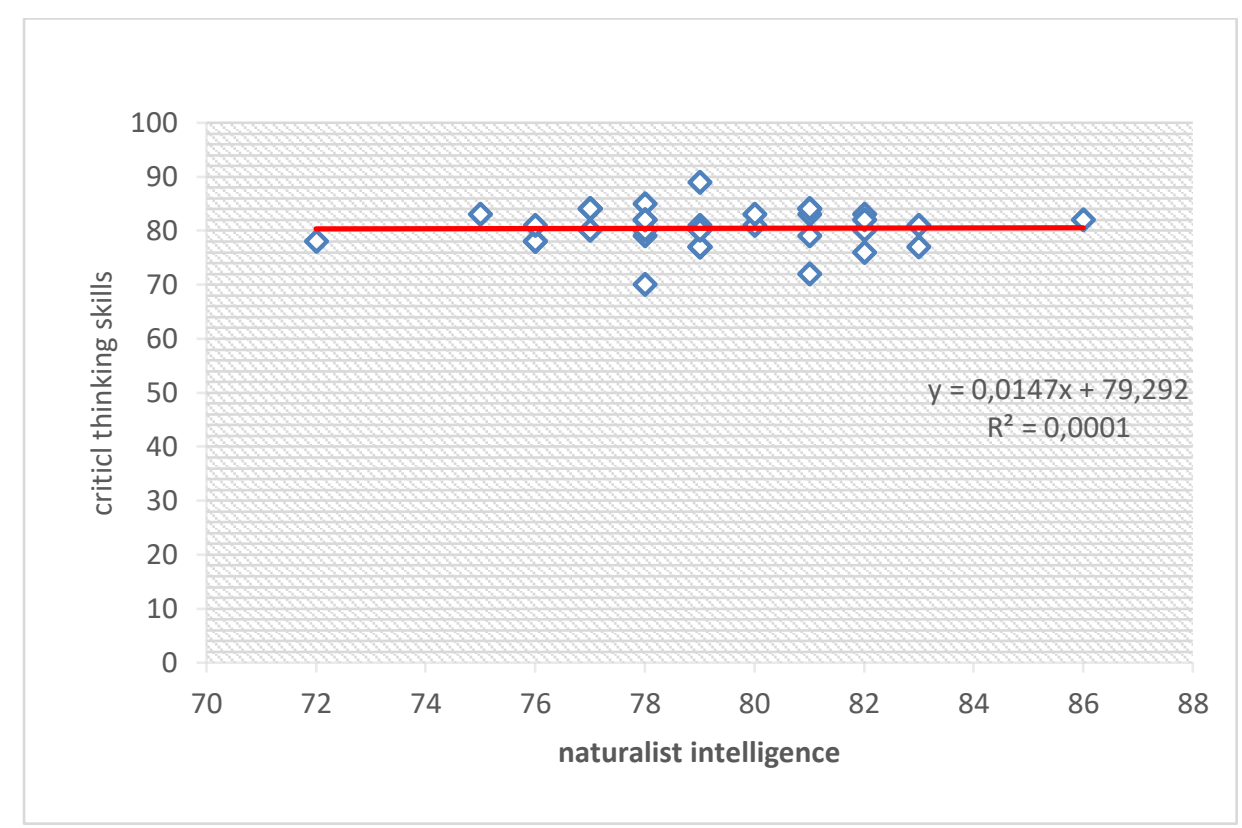

Figure 2.Correlation between student naturalist intelligence and critical thinking skills with expository methods 
Testing using this correlation test analysis did not show a positive relationship where $r=0.10$ meant there was no correlation with the equation $\mathrm{Y}=0.0147 \mathrm{x} \quad 79,292$ at the price of the determination coefficient $\mathrm{R} 2=0.0001$, this showed that there was no contribution of the student's naturalistic intelligence level to the student's critical thinking skills.

The results showed that the materials presented to students are the same and the application of problem based learning methods that do not run to the maximum. Teachers of science subjects are too minimal to provide a real example of the concepts of the subject matter, so some students are unable to follow the lessons according to the purpose of the learning. Whereas according to Arends the method of problem based learning is one of the learning method and teaching method that is very interesting and useful for every learner because in the approach of learning is very contextual and the problems are concrete rather than abstract concepts.

The nonattendance of these distinctions is on the grounds that the two techniques both have nearly similar focal points and hindrances, just as a similar condition of the learning condition so understudies will pick up understanding and association with the moderately same condition in order to apply a similar impact on naturalist insight and critical thinking skills. Environmental conditions thought about the equivalent here incorporate homerooms, research centers, bundle books and LKS, educators, showing materials and practicum materials, field practice areas and situations in generally comparable conditions.

The application of different learning methods does not provide naturalist intelligence and different critical thinking skills, it is possible that both methods have relatively similar characters and correspond to the relative state of students at the youth level and are initiate critical thinking. Thus, the relatively small differences between learning methods do not have a significant influence on the differences in naturalist intelligence and critical 
thinking skills between the sample classes in which the two methods are applied.

\section{CONCLUSION}

Based on the discussion and analysis of data from the results of this study can be made a few inferences as follows:

There is a difference in the level of naturalist intelligence of students between those studying and problem-based learning methods with students studying with regular learning methods as evidenced by the average difference test results where Fcount $=7.84>$ Ftable $=2.00$.

There is a difference in critical thinking skills between learning and problem-based learning methods with students learning with regular learning methods as evidenced by the average difference test results where Fcount $=$ $2.33>$ Ftable $=2.00$.

There is an influence between students' nauralis intelligence levels on critical thinking skills taught with problem-based learning methods as evidenced by the results of the analysis where tcount $=6.89>$ ttable $=2.03$, thus positively correlated with a determination coefficient of 0.58 . On the other hand, there was no influence between students' nauralis intelligence levels on critical thinking skills taught by the expository method as evidenced by the results of the analysis where tcount $=0.06=$ table $=2.03$, so it did not correlate positively with the coefficient of determination of 0.0001 .

\section{BIBLIOGRAPHY}

Adisendjaja, Y. H., Abdi, M. M. K., \& Fardhani, I. (2019). The influence of field trip on junior high School students' naturalistic intelligence and problem-solving skills in ecosystem subject. Jurnal Pendidikan IPA Indonesia, 8(3), 339-346.

Afriana, J., Permanasari, A., Fitriani, A. (2016). Project Based Learning Integrated to Stem to Enhance Elementary School's Students Scientific Literacy. Jurnal Pendidikan IPA Indonesia, 5(2), 261-262.

Aljaafil, E., \& Şahin, M. (2019). Critical thinking skills for primary education: the case in Lebanon. Turquoise International Journal of Educational 
Research and Social Studies Turquoise International Journal of Educational Research and Social Studies ISSN:, 1(1), 1-7.

Anazifa, R. . and, \& Djukri. (2017). Project- Based Learning and Problem- Based Learning: are They Effective to Improve Student' $S$ Thinking Skills. Jurnal Pendidikan IPA Indonesia, 6(2), 346-355.

Ardianto, D., \& Rubini, B. (2016). Comparison of students' scientific literacy in integrated science learning through model of guided discovery and problem based learning. Jurnal Pendidikan IPA Indonesia, 5(1), 31-37.

Asrizal, Amran, A., Ananda, A., Festiyed, F., \& Sumarmin, R. (2018). The development of integrated science instructional materials to improve students ' digital literacy in scientific approach. Jurnal Pendidikan IPA Indonesia, 7(4), 442-450.

Astuti, A. ., Aziz, A., Sumarti, S. ., \& Bharati, D. A. . (2019). Preparing 21st century teachers : implementation of 4C character's pre-service teacher through teaching practice preparing 21st century teachers : implementation of $4 \mathrm{c}$ character's pre-service teacher through teaching practice. Journal of Physics: Conference Series, 1233, 1-8.

Bedir, H. (2019). Pre-service ELT teachers' beliefs and perceptions on 21st century learning and innovation skills (4Cs). Journal of Language and Linguistic Studies, 15(1), 231-246.

Bustami, Y., Syafruddin, D., \& Afriani, R. (2018). The implementation of contextual learning to enhance biology students ' critical thinking skills. Jurnal Pendidikan IPA Indonesia, 7(4), 451-457.

Delaney, Y., Pattinson, B., Mccarthy, J., \& Beecham, S. (2017). Transitioning from traditional to problem-based learning in management education : the case of a frontline manager skills development programme. Innovations in Education and Teaching International, 54(3), 214-222.

Dewi, I. P. M., Suryadarma, I. G. P., Wilujeng, I., \& Wahyuningsih, S. (2017). The effect of science learning integrated with local potential of wood carving and pottery towards the junior high school students ' critical thinking skills. Jurnal Pendidikan IPA Indonesia, 6(1), 103-109.

Drago, V., \& Mih, V. (2015). Scientific Literacy in School. Procedia: Social and Behavioral Sciences, 209(July), 167-172.

Febrianti, Erni., Haryani, Sri., Supardi, K.I. (2015). Pengembangan Lembar Kerja (LKS) Materi Larutan Penyangga Model Problem Based Learning Bermuatan Karakter untuk Siswa SMA. Journal of Innovative Science Education, 4(1), 2.

Felleti, G. and Bound. 1997. Changing Problem-Based Learning. Bound, D. and Felleti, G. (Eds) The Chalengge of Problem Based Learning. (2 ${ }^{\text {nd }}$ Ed) (hlm. 1-14. London: Kogan Page).

Gani, A., Safitri, R., Mahyana, M. (2017). Improving the Visual-Spatial Intelligence and Result of Learning of Juniour High Scool Students with Multiple Intelligences-Based Students Worksheet Learning on Lens Materials. Jurnal Pendidikan IPA Indonesia, 6(1), 16-17. 
Gardner, H. (2003). Multiple Intelligences: Kecerdasan Majemuk: Teori dalam Praktek, Terjemahan: Alexander Sindoro, Batam: Interaksara.

Khasanah, A. N., Sajidan, \& Widoretno, S. (2017). Effectiveness of critical thinking indicator-based module in empowering student' $s$ learning outcome in. Jurnal Pendidikan IPA Indonesia, 6(1), 187-195.

Kurniawan, E., Muslim, S., Rahmadyanti, E., Aribowo, W., Kusumawati, N., Ismayati, E., \& Basuki, I. (2019). Vocational students readiness in the face of the Industrial Revolution 4.0 and the demands of life in the 21st Century Skills. Celebes Education Review, 1(1), 40-52.

Machin, A. (2014). Implementasi pendekatan saintifik, penanaman karakter dan konservasi pada pembelajaran materi pertumbuhan. Jurnal Pendidikan IPA Indonesia, 3(1), 28-35.

Martini, Rosdiana, L., Subekti, H., \& Setiawan, B. (2018). Strengthening students' characters and ecopreneurship through science, environment, technology, and society course. Jurnal Pendidikan IPA Indonesia, 7(2), 162-171.

Mutakinati, L., Anwari, I., \& Yoshisuke, K. (2018). Analysis Of Students' Critical Thinking Skill of Middle School Through STEM Education Project-Based Learning. Jurnal Pendidikan IPA Indonesia, 7(1), 54-65.

Nuswowati, M., Susilaningsih, E., Ramlawati, \& Kadarwati, S. (2017). Implementation of problem-based learning with green chemistry vision to improve creative thinking skill and students ' creative actions. Jurnal Pendidikan IPA Indonesia, 6(2), 221-228.

Puspitawati, R. P., Yuanita, L., Rahayu, Y. S., Indana, S., \& Susiyawati, E. (2018). Two problem solving cycles to achieve learning outcomes of thinking skills and plant anatomy concept mastery. Jurnal Pendidikan IPA Indonesia, 7(3), 312-321.

Putra, B. K. B., Prayitno, B. A., \& Mariadi. (2018). The effectiveness of guided inquiry and instad towards students ' critical thinking skills on circulatory system materials. Jurnal Pendidikan IPA Indonesia, 7(4), 476482.

Ratini, Muchtar, H., Suparman, M. A., Tamuri, A. H., \& Susanto, E. (2018). The influence of learning models and learning reliance. Jurnal Pendidikan IPA Indonesia, 7(4), 458-466.

Robert B. Levin, (2001). Energizing Teacher Education and Professional Development with Problem-Based Learning, Alexandria, Virgina USA: Assosiation for Supervision and Curriculum Development.

Rochmawati, A., Wiyanto, \& Ridlo, S. (2019). Analysis of 21 st Century Skills of Student on Implementation Project Based Learning and Problem Posing Models in Science Learning. Journal of Primary Education, 9(1), 58-67.

Rubini, B., Pusitasari, I. D., Ardianto, D., \& Hidayat, A. (2018). Science teachers ' understanding on science literacy and integrated science learning: lesson from teachers training. Jurnal Pendidikan IPA Indonesia, 7(3), 259-265.

Sada, C. (2019). Exploring t eaching learning p rocess in developing higher 
order thinking skill (HOT) to higher secondary school ( SMA) students in Pontianak. Journal of Education, Teaching, and Learning, 4(1), 228-232.

Setiawan, B., Innatesari, D. K., Sabtiawan, W. B., \& Sudarmin. (2017). The development of local wisdom-based natural science module to improve science literation of students. Jurnal Pendidikan IPA Indonesia, 6(1), 4954.

Suciati, Ali, M. N., Imaningtyas, C. D., Anggraini, A. F., \& Dermawan, Z. (2018). The profile of XI grade students ' scientific thinking abilities on scientific approach implementation. Jurnal Pendidikan IPA Indonesia, 7(3), 341346.

Suwono, H., Pratiwi, H. ., Susanto, H., \& Susilo, H. (2017). Enhancement of student' biological literacy and critical thinking of biology through sociobiological. Jurnal Pendidikan IPA Indonesia, 6(2). 